\title{
Characterization of a Novel Pseudomonas stutzeri Lipase/Esterase with Potential Application in the Production of Chiral Secondary Alcohols
}

\author{
Sven C. Lehmann1, Andy Maraite ${ }^{2}$, Max Steinhagen ${ }^{3}$, Marion B. Ansorge-Schumacher ${ }^{3 *}$ \\ ${ }^{1}$ Department of Biochemistry, Heinrich-Heine-Universität Düsseldorf, Düsseldorf, Germany \\ ${ }^{2}$ PS Biotech $\mathrm{GmbH}$, Aachen, Germany \\ ${ }^{3}$ Institute for Microbiology, Technische Universität Dresden, Dresden, Germany \\ Email: ${ }^{*}$ marion.ansorge@tu-dresden.de
}

Received 9 September 2014; revised 11 October 2014; accepted 5 November 2014

Copyright (C) 2014 by authors and Scientific Research Publishing Inc.

This work is licensed under the Creative Commons Attribution International License (CC BY). http://creativecommons.org/licenses/by/4.0/

c) (i) Open Access

\section{Abstract}

The search for new enzymes is facilitated by the rapidly growing number of genome sequences from different organisms. However, the discovery of functional proteins is still time intensive and complex alignments have to be performed. Herein, a genome database search identified a new, until now undescribed, putative lipase from Pseudomonas stutzeri strain A1501. The gene was cloned and expressed as functional protein in E. coli. A biochemical characterization provided an indication that the enzyme could be classified as an esterase with an alkaline $\mathrm{pH}$ optimum and a temperature optimum at $50^{\circ} \mathrm{C}$. The enzyme was able to perform the kinetic resolution of racemic esters and could therefore be an interesting candidate for chiral synthesis.

Keywords

Pseudomonas, Screening, Lipase, Esterase, Kinetics

\section{Introduction}

Lipolytic enzymes are of great interest for biotechnological processes. Their stereo- and regioselectivity, no cofactor dependency as well as their high stability and performance in diverse organic media make them highly interesting for chemical production.

\footnotetext{
*Corresponding author.
} 
In principal, lipolytic enzymes can be divided into two categories, namely esterases (E.C. 3.1.1.1) and lipases (E.C. 3.1.1.3) [1]. Both possess an $\alpha / \beta$ hydrolase fold including a catalytic triade, which is typically formed by the amino acids Ser-His-Asp/Glu [2] [3]. The esterases are restricted to small ester containing compounds, whereas lipases are able to convert water-insoluble long-chain triacylglycerides. A second difference is attributed to a flexible amphiphilic loop which is only present in lipases [4] [5]. This lid covers the active site in aqueous environments (close conformation) but undergoes a conformational change in contact to a lipid water interface (open conformation) [4] [6] [7]. This process, called interfacial activation, is exclusively found in lipases and was demonstrated to play a role in their activation [4].

Nowadays, these enzymes are used in the pharmaceutical and cosmetic industry, are involved in biodiesel processing and are applied in food industry [8]-[10]. Furthermore, their high regio- and stereoselectivity makes them interesting for the synthesis of chiral compounds [11]. Especially, bacterial enzymes play an important role in these processes and are preferred over plant or animal derived enzymes. They are easily accessible and can be produced in necessary quantities in cheap media and often downstream processing is simple. Among all, Pseudomonas sp. are the origin of a large amount of known esterases and lipases and some representatives are already commercially available [12] [13]. Most of them show a high thermal stability and are active in alkaline media [14]. Furthermore, the large substrate scope displays the versatility of esterases and lipases derived from Pseudomonas species. Pseudomonas stutzeri is an outstanding representative with a large genotypic diversity [15] and several genomic sequences from different strains are available in public databases.

Here we describe the identification of a new, until now undescribed, lipase/esterase through a mere database screening. Within the genome from Pseudomonas stutzeri strain A1501 a putative lipase of unknown function was found. The codon optimized gene of this candidate was cloned in different pET vectors and the resulting proteins were recombinantly expressed in E. coli. All constructs were tested for soluble expression and the best candidate was characterized in terms of buffer stability as well as $\mathrm{pH}$ and temperature optimum. Finally, the enzyme was investigated for ester hydrolysis to generate chiral alcohols.

\section{Material and Methods}

\subsection{Preparation of Expression Plasmids}

In order to avoid deficient translation, the lipase gene was ordered from Geneart (Regensburg, Germany) as synthetic gene with optimized codon usage for expression in E. coli. Different vectors were chosen (pET32b+ (Trx-tag), pET39b+ (DsbA-tag), pET40b+ (DsbC-tag) and pET44b+ (NusA-tag)) to achieve tag-mediated soluble expression of the corresponding proteins. Appropriate primer pairs were used to amplify the lipase gene by standard PCR methodology using Pfu DNA polymerase (Promega, Fitchburg, USA) and to prolong the sequence by the restriction sites for NcoI or SacI (forward) and XhoI (reverse). After purification of the PCR products, double digestion of the PCR fragments as well as all vectors was performed in accordance to the manufacturer's protocol. Finally, lipasegene and vectors were ligated by T4 ligase (Thermo Fisher Scientific, Waltham, USA) at $22^{\circ} \mathrm{C}$ overnight. The resulting constructs were transformed into E. coli DH5 $\alpha$ and correctness of all constructs was confirmed by sequencing of the entire coding sequence (Eurofins MWG Operon, Ebersberg, Germany).

\subsection{Expression and Purification of Functional Lipase/Esterase}

Functional plasmids were transformed into E. coli BL21 (DE3) and cells were grown overnight at $37^{\circ} \mathrm{C}$ in $5 \mathrm{~mL}$ LB medium with the appropriate antibiotic. Antibiotic concentration was $100 \mu \mathrm{g} / \mathrm{mL}$ for ampicillin and 50 $\mu \mathrm{g} / \mathrm{mL}$ for kanamycin, respectively. The preparatory culture was transferred into the main culture (500 mL TB media in a $2 \mathrm{~L}$ Erlenmeyer flask), grown for several hours at $37^{\circ} \mathrm{C}$ and protein expression was induced with IPTG (0.1 mM final concentration) at an $\mathrm{OD}_{600}$ of 1.5 . Low temperature expression was chosen at $17^{\circ} \mathrm{C}$ for $24 \mathrm{~h}$ and $150 \mathrm{rpm}$. The resulting proteins were named Trx-lipase, DsbA-lipase, DsbC-lipase and NusA-lipase, respectively.

The cells were harvested by centrifugation $\left(7500 \times \mathrm{g}\right.$ for $5 \mathrm{~min}$ at $\left.4^{\circ} \mathrm{C}\right)$, washed in $50 \mathrm{mM}$ Tris- $\mathrm{HCl}$ buffer (pH 8.0) and finally resuspended in $5 \mathrm{~mL}$ of the same buffer. Cell lysis was done by sonification and the soluble protein fraction was separated by centrifugation $\left(15,000 \times \mathrm{g}\right.$ for $20 \mathrm{~min}$ at $\left.4^{\circ} \mathrm{C}\right)$.

Purification was achieved by IMAC using an ÄKTA FPLC system (GE Healthcare, Chalfont St Giles, UK) 
equipped with a $5 \mathrm{~mL}$ Ni-NTA superflow cartridge (Qiagen, Venlo, Netherlands). For all steps a flow rate of 5 $\mathrm{mL} / \mathrm{min}$ was applied. Prior to the purification, the column was equilibrated with $5-15 \mathrm{~mL}$ equilibration buffer (50 mM Tris-HCl, $0.3 \mathrm{M} \mathrm{NaCl}, 20 \mathrm{mM}$ imidazole, $\mathrm{pH}$ 8.0). The protein containing sample was supplemented with $20 \mathrm{mM}$ imidazole, filtered through a sterile filter $(0.22 \mu \mathrm{m})$ and injected into the chromatography system. After sample loading, the column was washed with $15 \mathrm{~mL}$ equilibration buffer. Elution of the target protein was obtained by an elution gradient from $20-500 \mathrm{mM}$ imidazole over $10 \mathrm{~mL}$ and a final step using $5 \mathrm{~mL}$ elution buffer (50 mM Tris-HCl, $0.3 \mathrm{M} \mathrm{NaCl}, 500 \mathrm{mM}$ imidazole, $\mathrm{pH}$ 8.0). Protein containing fractions were pooled and residual imidazole was removed by a desalting step using a HiPrep 26/10 Desalting column (GE Healthcare, Chalfont St Giles, UK). The column was equilibrated with desalting buffer (1 mM Tris-HCl, pH 8.0) and desalting occurred over two column volumes at a flow rate of $5 \mathrm{~mL} / \mathrm{min}$. Afterwards, the protein preparation was lyophilized and stored at $-80^{\circ} \mathrm{C}$.

\subsection{Characterization of the New Lipase/Esterase}

Lipase lyophilisates were resolved in the appropriate buffer. Protein concentrations were determined by Bradford assay and a stock solution $(100 \mu \mathrm{g} / \mathrm{mL})$ was further diluted according to the specific assay. In general, enzyme activity assays contained $1780 \mu \mathrm{L}$ of the corresponding buffer, $20 \mu \mathrm{L}$ enzyme solution and $200 \mu \mathrm{L}$ substrate solution.

\subsection{Specific Activity and Substrate Specificity}

Substrate specificity was determined using a set of p-nitrophenyl esters with saturated carboxylates ranging from $\mathrm{C}_{4}$ to $\mathrm{C}_{16}$ (p-nitrophenyl butyrate (pNPB), p-nitrophenylcaprylate (pNPC), p-nitrophenyllaurate (pNPL), p-nitrophenylpalmitate (pNPP)). Esters were dissolved in 2-propanol to form the substrate solution (1 mM). In these experiments $50 \mathrm{mM}$ Tris- $\mathrm{HCl} \mathrm{pH}$ 8.0, supplemented with $1 \%$ triton X-100 as surfactant, served as standard buffer. The absorption at $405 \mathrm{~nm}$ (absorption maximum of p-nitrophenol (pNP)) was investigated over 2 min and the slope was calculated to determine specific activities. The molar extinction coefficient of pNP for the different $\mathrm{pH}$ values and buffers was determined separately (data not shown).

\subsection{Stability, Temperature Optimum and pH Optimum}

Determination of the stability as well as temperature and $\mathrm{pH}$ optimum was performed with the activity assay described above. Noteworthy, no surfactant was supplemented in the buffers and the buffer strength was $50 \mathrm{mM}$ each. Hydrolysis of pNPC served as standard for all measurements. The stability was tested by incubation of the enzyme in buffer at room temperature over several days. The temperature optimum was determined in potassium phosphate buffer $\mathrm{pH}$ 8.0. The $\mathrm{pH}$ optimum was investigated over a $\mathrm{pH}$ range of $\mathrm{pH} 4-11$. Therefore, the following buffers were used: citrate buffer ( $\mathrm{pH} 4$ - 6), potassium phosphate buffer ( $\mathrm{pH} 6-8$ ), Tris-HCl buffer (pH 8 - 9) and CAPS buffer ( $\mathrm{pH} 10$ - 11). If buffers with $\mathrm{pH}<7$ were used, the absorption maximum was measured at $320 \mathrm{~nm}$ instead of $405 \mathrm{~nm}$.

\subsection{Enantioselectivity of Lipase from $P$. stutzeri}

Enantioselectivity was determined by the enzymatic hydrolysis of $\alpha$-methylbenzyl butyrate (MBB) to 1phenylethanol. The assay was performed in Tris- $\mathrm{HCl} \mathrm{pH} 8.0$, the starting concentration of MBB was $400 \mathrm{mM}$. Reaction vessels were shaken at $25^{\circ} \mathrm{C}$ and samples of $200 \mu \mathrm{L}$ were taken periodically. $1 \mathrm{~mL}$ ethyl acetate was added to the samples and intensive mixing transferred the products to the water-free phase. Samples were dried with ammonium sulfate to remove remaining water and analyzed by gas chromatography. R- and S-enantiomer of 1-phenylethanol were separated in a GC 2010 gas chromatograph (Shimadzu, Kyoto, Japan) equipped with an AOC-20i auto injector. For separation of all chiral compounds a FS-Cyclodex $\beta$-I/P column (CS—Chromatographie Service GmbH, Langerwehe, Germany) was used. The carrier gas $\left(\mathrm{N}_{2}\right)$ was applied with a pressure of 50 $\mathrm{kPa}$ and $1 \mu \mathrm{L}$ of the extracted samples were injected on the column with split flow. The optimized method was $60^{\circ} \mathrm{C}$ for $2 \mathrm{~min}, 60^{\circ} \mathrm{C}-90^{\circ} \mathrm{C}$ for $5 \mathrm{~min}$ (slope: $6^{\circ} \mathrm{C} / \mathrm{min}$ ), $90^{\circ} \mathrm{C}-150^{\circ} \mathrm{C}$ for $20 \mathrm{~min}$ (slope: $3^{\circ} \mathrm{C} / \mathrm{min}$ ) and $150^{\circ} \mathrm{C}$ for $2 \mathrm{~min}$. Retention times were $5.4 \mathrm{~min}$ for vinyl butyrate, $22.1 \mathrm{~min}$ for $(R)-1$-phenylethanol and $22.6 \mathrm{~min}$ for (S)-1-phenylethanol. 


\subsection{Software Tools and Databases}

Nucleotide and amino acid sequences of the different proteins were found at NCBI and homology arrangements were performed by the BLAST tool of NCBI. The visualized model of the $P$. stutzeri lipase was obtained from Swiss-Model [16]-[18] and processed and displayed with Yasara v.14.2.12.

\section{Results and Discussion}

The P. stutzeri A1501 genome is completely sequenced and available on public databases (NCBI reference sequence number: NC_009434.1, GenBank: CP000304.1). Within the sequence between base 4,349,096 and 4,349,944 a probable reading frame for an unknown lipase/esterase was spotted. This gene was formerly annotated to encode for a lipase and also the protein sequence can be found in the NCBI database (NCBI reference sequence: YP_001174476.1). However, the functional protein was neither described or expressed nor characterized. After a protein BLAST analysis was performed, it turned out that the enzyme was conserved over different $P$. stutzeri strains with sequence identities over $90 \%$. Furthermore, it is closely related to a lipase from $P$. mendocina [19] (PDB ID: 2fx5). Apart from the fact that the new lipase/esterase possesses an N-terminal overhang of 23 amino acids, both enzymes have a high grade of similarity (identities: 83\%, positives: 92\%, gaps: 0\%). The alignment of both sequences is depicted in Figure 1(a). The missing N-terminal peptide (first 23 amino acids) was identified to be a signal peptide using SignalP [20]. Based on the solved structure of $P$. mendocina lipase, a putative model of $P$. stutzeri lipase/esterase was created via Swiss-Model web server [16]-[18] giving a first impression of the possible enzyme structure and illustrating the typical $\alpha / \beta$ hydrolase fold (Figure 1(b)). The centre forms a parallel $\beta$-sheet probably containing the catalytic groups. This $\beta$-sheet is surrounded by loops and helices, whereby one of the last may be the lid which covers the catalytic centre. As mentioned above, lipases and esterases are hardly distinguishable when comparing their primary sequences [2]. Therefore, it is not possible to determine the correct classification of the enzyme from the alignment and further biochemical studies have to be performed.

\subsection{Cloning, Expression and Purification of the New Lipase/Esterase (P. stutzeri)}

The identified gene was synthesized and cloned into different expression vectors. Noteworthy, codon usage of the wild type gene was adapted for expression in E. coli to avoid incorrect translation. Unfortunately, expression without solubilizing tags resulted in insoluble protein located in inclusion bodies (data not shown). Therefore, the expression of fusion proteins with enhanced solubility was chosen [21], which was formerly described to be transferable to lipases. For example, Narayanan and co-workers reported the soluble expression of a lipase from Burholderia when fused to DsbA or DsbC [22]. Also the soluble expression of lipase B from Candida antarctica was improved by N-terminal addition of a thioredoxin tag [23]. We selected four different tags, namely thioredoxin (Trx, $12 \mathrm{kDa}$ ), two thiol: disulfide interchange proteins (DsbA, $23 \mathrm{kDa}$ and DsbC, $25.5 \mathrm{kDa}$ ) and the transcription termination/antitermination protein NusA (NusA, $55 \mathrm{kDa}$ ). Expression plasmids were constructed resulting in the expression of the lipase/esterase with the respective $\mathrm{N}$-terminal tag. The proteins were named Trx-lipase, DsbA-lipase, DsbC-lipase and NusA-lipase. Overexpression in E. coli BL21 (DE3) resulted in soluble expression of all four fusion proteins (Figure 2(a)). According to their molecular mass, all the constructs were clearly assignable. Since smaller tags would have lower influence on the overall structure of the fusion protein, its enzyme activity was investigated. All the fusion proteins were active with the highest activity for Trx-lipase (Trx-Lip, Figure 2(b)). Because of the smallest tag size and the highest activity in the cell raw extracts, Trx-Lip was selected for further investigation. Purification by IMAC was followed by desalting and lyophilisation and produced the target enzyme in adequate purity.

\subsection{Biochemical Characterization}

First of all, substrate range and specific activities of purified Trx-Lip were determined. Therefore, a set of different p-nitrophenyl esters, ranging from $\mathrm{C}_{4}$ to $\mathrm{C}_{16}$ was used (Figure 3). Trx-Lip showed maximum activity towards middle chain substrates $\left(C_{4}\right.$ to $\left.C_{8}\right)$, whereas esters with unsaturated long chain fatty acids $\left(C_{12}\right.$ to $\left.C_{16}\right)$ were converted very slowly or not at all. The $\mathrm{K}_{\mathrm{M}}$-value for the best substrate (pNPB) was determined to be 0.43 $\mathrm{mM}$ calculated by Lineweaver-Burk plot. This indicates a high affinity to short and medium chain fatty acid substrates. 


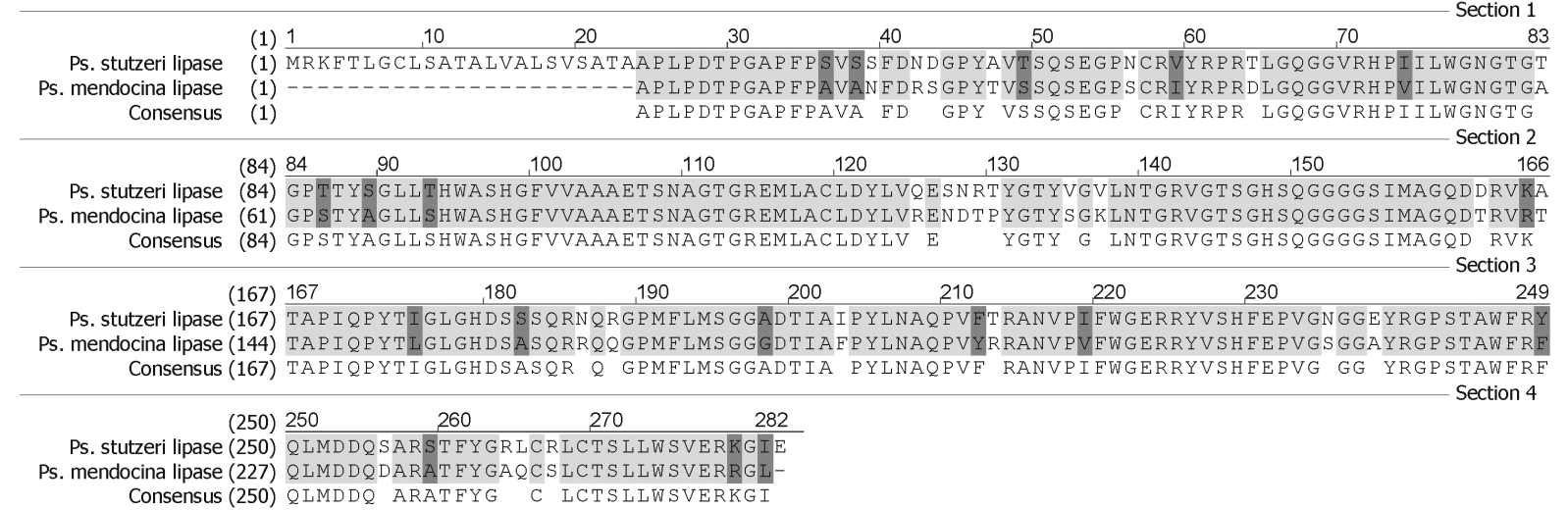

(a)

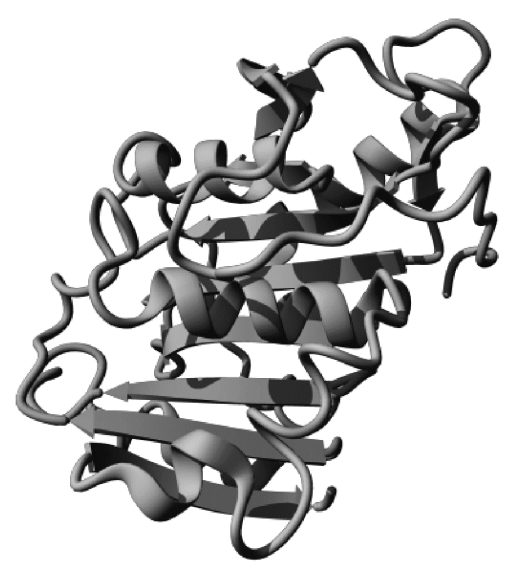

(b)

Figure 1. Alignment and putative model of the identified lipase/esterase from Pseudomonas stutzeri A1501. (a) Alignment of the putative functional gene and a closely related lipase gene from $P$. mendocina. Bright grey: identical amino acids, dark grey: similar amino acids, white: no consensus; (b) Homology model of Pseudomonas stutzeri A1501 lipase/esterase. The crystal structure of Pseudomonas mendocina lipase (identities: 82\%, PDB 2fx5A) is the best available structural approximation and was used to model the possible structure. The centre forms a parallel $\beta$-sheet, which is surrounded by helices, whereby one of them may be the lid covering the catalytic centre. The model was obtained from Swiss-Model [16]-[18], processed and displayed with Yasara v.14.2.12.

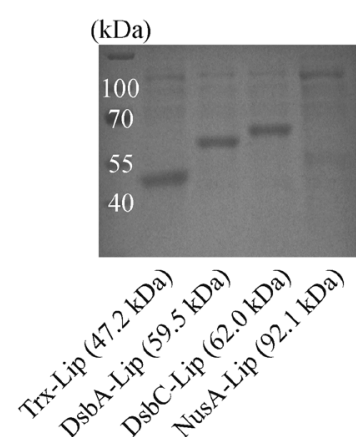

(a)

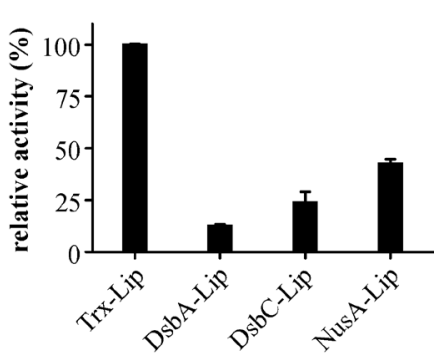

(b)

Figure 2. SDS-PAGE and activity of all fusion proteins. Trx-Lip-lipase N-terminally tagged with thioredoxin, DsbA-Lip -lipase N-terminally tagged with DsbA, DsbC-Lip-lipase N-terminally tagged with DsbC, NusA-Lip-lipase N-terminally tagged with NusA. (a) SDS-PAGE of cell raw extracts from the different investigated lipase variants after expression in $E$. coli. A soluble expression could be realized with all four fusion proteins; (b) Enzymatic hydrolysis of p-nitrophenolbutyrate (pNPB) by cell raw extracts. All four variants were active after recombinant expression in E. coli, with Trx-Lip showing the highest activity for pNPB. 


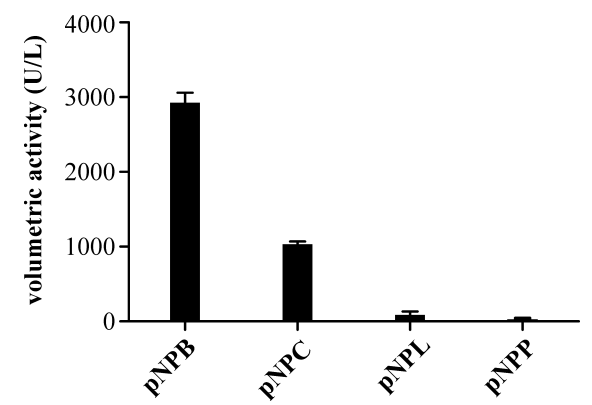

Figure 3. Volumetric activities of Trx-Lip for substrates with different chain length. pNPB: p-nitrophenylbutyrate, pNPC: p-nitrophenylcaprylate, pNPL: p-nitrophenyllaurate, pNPP: p-nitrophenylpalmitate; The highest activity was observed for pNPB hydrolysis.

It was suggested that a preliminary classification of esterases and lipases can be done from their substrate spectrum using p-nitrophenyl esters [24]. Esterases hydrolyze small alkyl esters like pNPB, while lipases are able to hydrolyze long chain fatty acid esters like pNPP. Nowadays, this classification is controversially discussed [25] [26], but still the hydrolytic behaviour can give a first hint. Our findings suggested that Trx-Lip corresponded more to an esterase than to a lipase. Furthermore, interfacial activation of the enzyme could not be observed, which is in accordance to the behaviour of the structurally related lipase from P. mendocina [19].

Especially for industrial applications, it is necessary to know which conditions can be exposed to a certain enzyme. First, the stability of the recombinant enzyme was tested in buffer. Lyophilized Trx-Lip was resuspended in Tris-HCl buffer $\mathrm{pH} 8.0$ and incubated at room temperature. After $24 \mathrm{~h}$ a relative activity of $96 \%$ was detected and even after 8 days the lipase still displayed a residual activity of 86\% (Figure 4(a)). Additionally, temperature and $\mathrm{pH}$ spectra were investigated (Figure 4(b) and Figure 4(c)). The temperature spectrum of Trx-Lip showed a linear slope with increasing temperature and a maximum activity at $50^{\circ} \mathrm{C}$. At higher temperatures the lipase became unstable and lost its activity very fast. The $\mathrm{pH}$ range of Trx-Lip was very broad with the highest activity between $\mathrm{pH} 7.5-10$ and a maximum at $\mathrm{pH}$ 9. The high activity at alkaline $\mathrm{pH}$ and the temperature optimum above $40^{\circ} \mathrm{C}$ referred this enzyme to typical representatives of lipases and esterases [14]. Additionally, these facts indicate the potential application of the new lipase in industrial processes, for example in the detergent industry.

\subsection{Enantioselectivity of Lipase from $P$. stutzeri}

Enantioselective synthesis of chiral compounds is a major concern in modern pharmaceutical production. Lipases display attractive catalysts because they can either hydrolyse prochiral substrates or convert one enantiomer from a racemic mixture [27]. This increases reactant flexibility and enables different synthetic routes. The possible application of the new enzyme was investigated by the hydrolysis of $\alpha$-methylbenzyl butyrate to 1-phenylethanol. A commercial lipase from P. stutzeri (Lipase $T L^{\circledR}$ ), which has been shown to process bulky secondary alcohols [28] [29], was used as positive control. Resulting products were analysed by GC and the amount was calculated from appropriate standard curves (Figure 5).

Not surprisingly, the specific activity of Lipase $\mathrm{TL}^{\circledR}$ (starting activity: $5660 \mathrm{U} / \mathrm{mg}$ protein) is higher than that of Trx-Lip (starting activity: $523 \mathrm{U} / \mathrm{mg}$ protein). Both enzymes are able to hydrolyse the R-enantiomer with good enantiomeric excess (ee). The ee for Lipase $\mathrm{TL}^{\circledR}$ was calculated to be $>99 \%$. In the first $2 \mathrm{~h}$, also Trx-Lip showed ee-values $>93 \%$, but within the next $15 \mathrm{~h}$ the ee decreased to $83 \%$. Nevertheless, the exclusive hydrolysis of the R-enantiomer at the beginning indicates not only a stereoselective preference, but also illustrates the ability to perform kinetic resolution of chiral esters. Furthermore, Lipase $\mathrm{TL}^{\circledR}$ is able to perform the (dynamic) kinetic resolution of $\alpha$-hydroxyketones [29] [30]. In our experiments, Trx-Lip was not able to catalyse kinetic resolution of benzoin, and the sterically less complex $\alpha$-hydroxypropiophenone could also not be converted (data not shown). Despite the same origin (both enzyme preparations are from Pseudomonas stutzeri), Trx-Lip behaves different from Lipase $\mathrm{TL}^{\circledR}$ and was thereby not a component of the commercial product. This illustrates that Trx-Lip indeed presents a new until now unknown lipase/esterase. It is known that the enantioselectivity of lipases can be influenced by many parameters like the choice of solvent [31] or by immobilization [32]. Optimized conditions could thereby improve the stereoselectivity of the new lipase/esterase. Herein also just one 


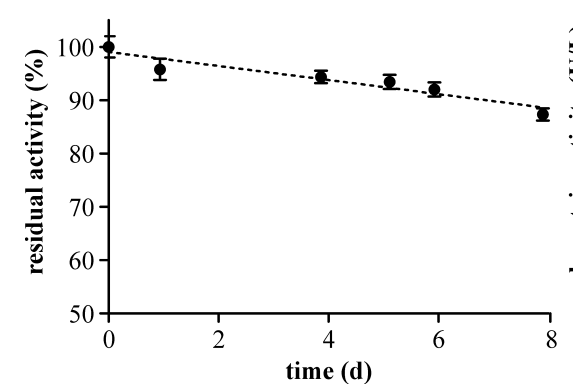

(a)

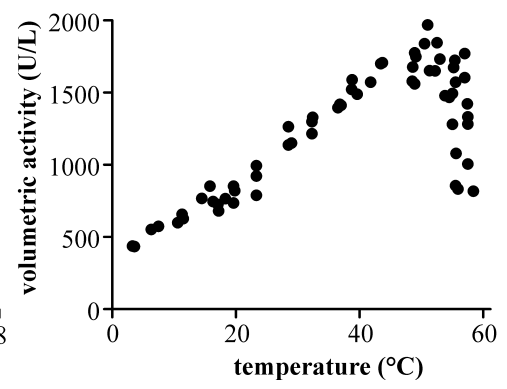

(b)

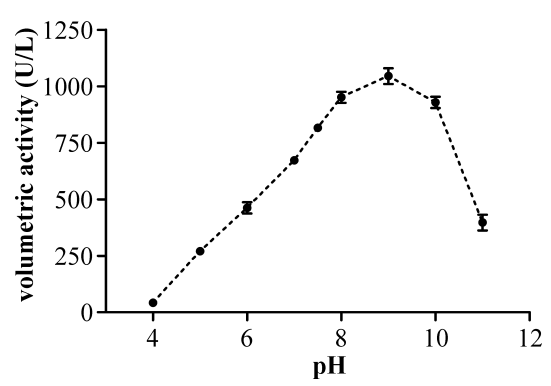

(c)

Figure 4. Biochemical characterization of Trx-Lip. (a) Stability of Trx-Lip in buffer, even after 8 days $>85 \%$ residual activity was observable; (b) Volumetric activity of Trx-Lip at varying temperatures, the temperature optimum is $\sim 50^{\circ} \mathrm{C}$; (c) Volumetric activity of Trx-Lip at varying $\mathrm{pH}$ values, the $\mathrm{pH}$ optimum was determined to be at $\mathrm{pH}$ 9.0.

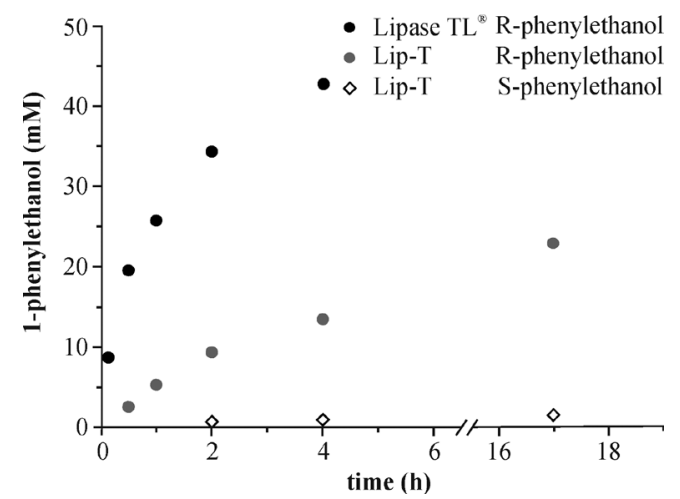

Figure 5. Hydrolysis of $\alpha$-methylbenzyl butyrate by Trx-Lip and Lipase TL ${ }^{\circledR}$. Lipase TL $^{\circledR}$ hydrolyzes exclusively the R-enantiomer (black). In contrast Trx-Lip hydrolyzes the R-enantiomer (gray) faster than the S-enantiomer (white), but not exclusively.

substrate was tested for enzymatic performance and enantiomeric selectivity. Additional substrate screenings could identify enzyme requirements and will lead to a better understanding of this new enzyme.

\section{Conclusion}

In summary, a database search identified a new lipase/esterase that was related to lipase from P. mendocina. This enzyme could be expressed in an active form in E. coli when fused to different solubilizing tags. The Trx-tag turned out to be the most effective tag due to its small size and outstanding solubilizing performance. The resulting fusion protein (Trx-Lip) was purified and biochemically characterized. It showed the highest activity to mid-chain $\left(\mathrm{C}_{4}-\mathrm{C}_{8}\right)$ esters, and had a $\mathrm{pH}$ optimum of 9.0 and a temperature optimum at $50^{\circ} \mathrm{C}$. Furthermore, stereospecificity was tested by the hydrolysis of $\alpha$-methylbenzyl butyrate. The enzyme was R-specific and was able to perform the kinetic resolution of chiral esters. Although a substrate screening would be necessary to gain further information on enzyme properties, the new lipase/esterase represents a promising candidate for the synthesis of chiral compounds also in industrial processes. Additionally, the authors would propose to classify the enzyme as an esterase instead of a lipase.

\section{References}

[1] Bornscheuer, U.T. (2002) Microbial Carboxyl Esterases: Classification, Properties and Application in Biocatalysis. FEMS Microbiology Reviews, 26, 73-81. http://dx.doi.org/10.1111/j.1574-6976.2002.tb00599.x

[2] Cygler, M., Schrag, J.D., Sussman, J.L., Harel, M., Silman, I., Gentry, M.K. and Doctor, B.P. (1993) Relationship between Sequence Conservation and Three-Dimensional Structure in a Large Family of Esterases, Lipases, and Related Proteins. Protein Science, 2, 366-382. http://dx.doi.org/10.1002/pro.5560020309

[3] Ollis, D.L., Cheah, E., Cygler, M., Dijkstra, B., Frolow, F., Franken, S.M., Harel, M., Remington, S.J., Silman, I., 
Schrag, J., et al. (1992) The Alpha/Beta Hydrolase Fold. Protein Engineering, 5, 197-211. http://dx.doi.org/10.1093/protein/5.3.197

[4] Brzozowski, A.M., Derewenda, U., Derewenda, Z.S., Dodson, G.G., Lawson, D.M., Turkenburg, J.P., Bjorkling, F., Huge-Jensen, B., Patkar, S.A. and Thim, L. (1991) A Model for Interfacial Activation in Lipases from the Structure of a Fungal Lipase-Inhibitor Complex. Nature, 351, 491-494. http://dx.doi.org/10.1038/351491a0

[5] Sarda, L. and Desnuelle, P. (1958) Actions of Pancreatic Lipase on Esters in Emulsions. Biochimica et Biophysica Acta, 30, 513-521. http://dx.doi.org/10.1016/0006-3002(58)90097-0

[6] Brady, L., Brzozowski, A.M., Derewenda, Z.S., Dodson, E., Dodson, G., Tolley, S., Turkenburg, J.P., Christiansen, L., Huge-Jensen, B., Norskov, L., et al. (1990) A Serine Protease Triad Forms the Catalytic Centre of a Triacylglycerol Lipase. Nature, 343, 767-770. http://dx.doi.org/10.1038/343767a0

[7] Winkler, F.K., D’Arcy, A. and Hunziker, W. (1990) Structure of Human Pancreatic Lipase. Nature, 343, $771-774$. http://dx.doi.org/10.1038/343771a0

[8] Jaeger, K.E. and Eggert, T. (2002) Lipases for Biotechnology. Current Opinion in Biotechnology, 13, 390-397. http://dx.doi.org/10.1016/S0958-1669(02)00341-5

[9] Hasan, F., Shah, A.A. and Hameed, A. (2006) Industrial Applications of Microbial Lipases. Enzyme and Microbial Technology, 39, 235-251. http://dx.doi.org/10.1016/j.enzmictec.2005.10.016

[10] Ansorge-Schumacher, M.B. and Thum, O. (2013) Immobilised Lipases in the Cosmetics Industry. Chemical Society Reviews, 42, 6475-6490. http://dx.doi.org/10.1039/c3cs35484a

[11] Turner, N.J. (2010) Deracemisation Methods. Current Opinion in Chemical Biology, 14, 115-121. http://dx.doi.org/10.1016/j.cbpa.2009.11.027

[12] Gupta, R., Gupta, N. and Rathi, P. (2004) Bacterial Lipases: An Overview of Production, Purification and Biochemical Properties. Applied Microbiology and Bbiotechnology, 64, 763-781. http://dx.doi.org/10.1007/s00253-004-1568-8

[13] Soberon-Chavez, G. and Palmeros, B. (1994) Pseudomonas Lipases: Molecular Genetics and Potential Industrial Applications. Critical Reviews in Microbiology, 20, 95-105. http://dx.doi.org/10.3109/10408419409113549

[14] Gilbert, E.J. (1993) Pseudomonas Lipases: Biochemical Properties and Molecular Cloning. Enzyme and Microbial Technology, 15, 634-645. http://dx.doi.org/10.1016/0141-0229(93)90062-7

[15] Lalucat, J., Bennasar, A., Bosch, R., Garcia-Valdes, E. and Palleroni, N.J. (2006) Biology of Pseudomonas stutzeri. Microbiology and Molecular Biology Reviews, 70, 510-547. http://dx.doi.org/10.1128/MMBR.00047-05

[16] Biasini, M., Bienert, S., Waterhouse, A., Arnold, K., Studer, G., Schmidt, T., Kiefer, F., Cassarino, T.G., Bertoni, M., Bordoli, L. and Schwede, T. (2014) Swiss-Model: Modelling Protein Tertiary and Quaternary Structure Using Evolutionary Information. Nucleic Acids Research, 42, W252-W258. http://dx.doi.org/10.1093/nar/gku340

[17] Arnold, K., Bordoli, L., Kopp, J. and Schwede, T. (2006) The Swiss-Model Workspace: A Web-Based Environment for Protein Structure Homology Modelling. Bioinformatics, 22, 195-201. http://dx.doi.org/10.1093/bioinformatics/bti770

[18] Benkert, P., Biasini, M. and Schwede, T. (2011) Toward the Estimation of the Absolute Quality of Individual Protein Structure Models. Bioinformatics, 27, 343-350. http://dx.doi.org/10.1093/bioinformatics/btq662

[19] Boston, M., Requadt, C., Danko, S., Jarnagin, A., Ashizawa, E., Wu, S., Poulose, A.J. and Bott, R. (1997) Structure and Function of Engineered Pseudomonas mendocina Lipase. In: Byron Rubin, E.A.D., Ed., Methods in Enzymology, Academic Press, Waltham, 298-317.

[20] Petersen, T.N., Brunak, S., von Heijne, G. and Nielsen, H. (2011) Signalp 4.0: Discriminating Signal Peptides from Transmembrane Regions. Nature Methods, 8, 785-786. http://dx.doi.org/10.1038/nmeth.1701

[21] Esposito, D. and Chatterjee, D.K. (2006) Enhancement of Soluble Protein Expression through the Use of Fusion Tags. Current Opinion in Biotechnology, 17, 353-358. http://dx.doi.org/10.1016/j.copbio.2006.06.003

[22] Narayanan, N., Khan, M. and Chou, C.P. (2011) Enhancing Functional Expression of Heterologous Burkholderia Lipase in Escherichia coli. Molecular Biotechnology, 47, 130-143. http://dx.doi.org/10.1007/s12033-010-9320-3

[23] Liu, D., Schmid, R. D. and Rusnak, M. (2006) Functional Expression of Candida antarctica Lipase B in the Escherichia coli Cytoplasm-A Screening System for a Frequently Used Biocatalyst. Applied Microbiology and Biotechnology, 72, 1024-1032. http://dx.doi.org/10.1007/s00253-006-0369-7

[24] Vorderwulbecke, T., Kieslich, K. and Erdmann, H. (1992) Comparison of Lipases by Different Assays. Enzyme and Microbial Technology, 14, 631-639. http://dx.doi.org/10.1016/0141-0229(92)90038-P

[25] Chahinian, H., Nini, L., Boitard, E., Dubes, J.P., Comeau, L.C. and Sarda, L. (2002) Distinction between Esterases and Lipases: A Kinetic Study with Vinyl Esters and Tag. Lipids, 37, 653-662. http://dx.doi.org/10.1007/s11745-002-0946-7

[26] Lopes, D.B., Fraga, L.P., Fleuri, L.F. and Macedo, G.A. (2011) Lipase and Esterase-To What Extent Can This Clas- 
sification Be Applied Accurately? Science and Technology of Food, 31, 608-613.

[27] Liu, H.L. and Anthonsen, T. (2002) Enantiopure Building Blocks for Chiral Drugs from Racemic Mixtures of Secondary Alcohols by Combination of Lipase Catalysis and Mitsunobu Esterification. Chirality, 14, 25-27. http://dx.doi.org/10.1002/chir.10037

[28] Yamamoto, T., Shibata, N., Takashima, M., Nakamura, S., Toru, T., Matsunaga, N. and Hara, H. (2008) Enzymatic Resolution and Evaluation of Enantiomers of Cis-5[Prime or Minute]-Hydroxythalidomide. Organic \& Biomolecular Chemistry, 6, 1540-1543. http://dx.doi.org/10.1039/b802459f

[29] Maraite, A., Hoyos, P., Carballeira, J.D., Cabrera, A.C., Ansorge-Schumacher, M.B. and Alcantara, A.R. (2013) Lipase from Pseudomonas stutzeri: Purification, Homology Modelling and Rational Explanation of the Substrate Binding Mode. Journal of Molecular Catalysis B-Enzymatic, 87, 88-98. http://dx.doi.org/10.1016/j.molcatb.2012.11.005

[30] Hoyos, P., Pace, V., Sinisterra, J.V. and Alcántara, A.R. (2011) Chemoenzymatic Synthesis of Chiral Unsymmetrical Benzoin Esters. Tetrahedron, 67, 7321-7329. http://dx.doi.org/10.1016/j.tet.2011.07.030

[31] Parida, S. and Dordick, J.S. (1991) Substrate Structure and Solvent Hydrophobicity Control Lipase Catalysis and Enantioselectivity in Organic Media. Journal of the American Chemical Society, 113, 2253-2259. http://dx.doi.org/10.1021/ja00006a051

[32] Palomo, J.M., Fernandez-Lorente, G., Mateo, C., Ortiz, C., Fernandez-Lafuente, R. and Guisan, J.M. (2002) Modulation of the Enantioselectivity of Lipases via Controlled Immobilization and Medium Engineering: Hydrolytic Resolution of Mandelic Acid Esters. Enzyme and Microbial Technology, 31, 775-783.

http://dx.doi.org/10.1016/S0141-0229(02)00169-2 
Scientific Research Publishing (SCIRP) is one of the largest Open Access journal publishers. It is currently publishing more than 200 open access, online, peer-reviewed journals covering a wide range of academic disciplines. SCIRP serves the worldwide academic communities and contributes to the progress and application of science with its publication.

Other selected journals from SCIRP are listed as below. Submit your manuscript to us via either submit@scirp.org or Online Submission Portal.
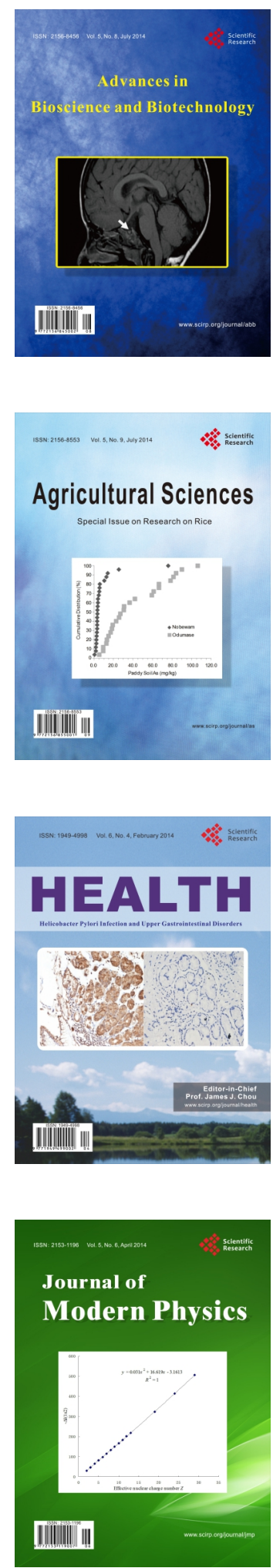
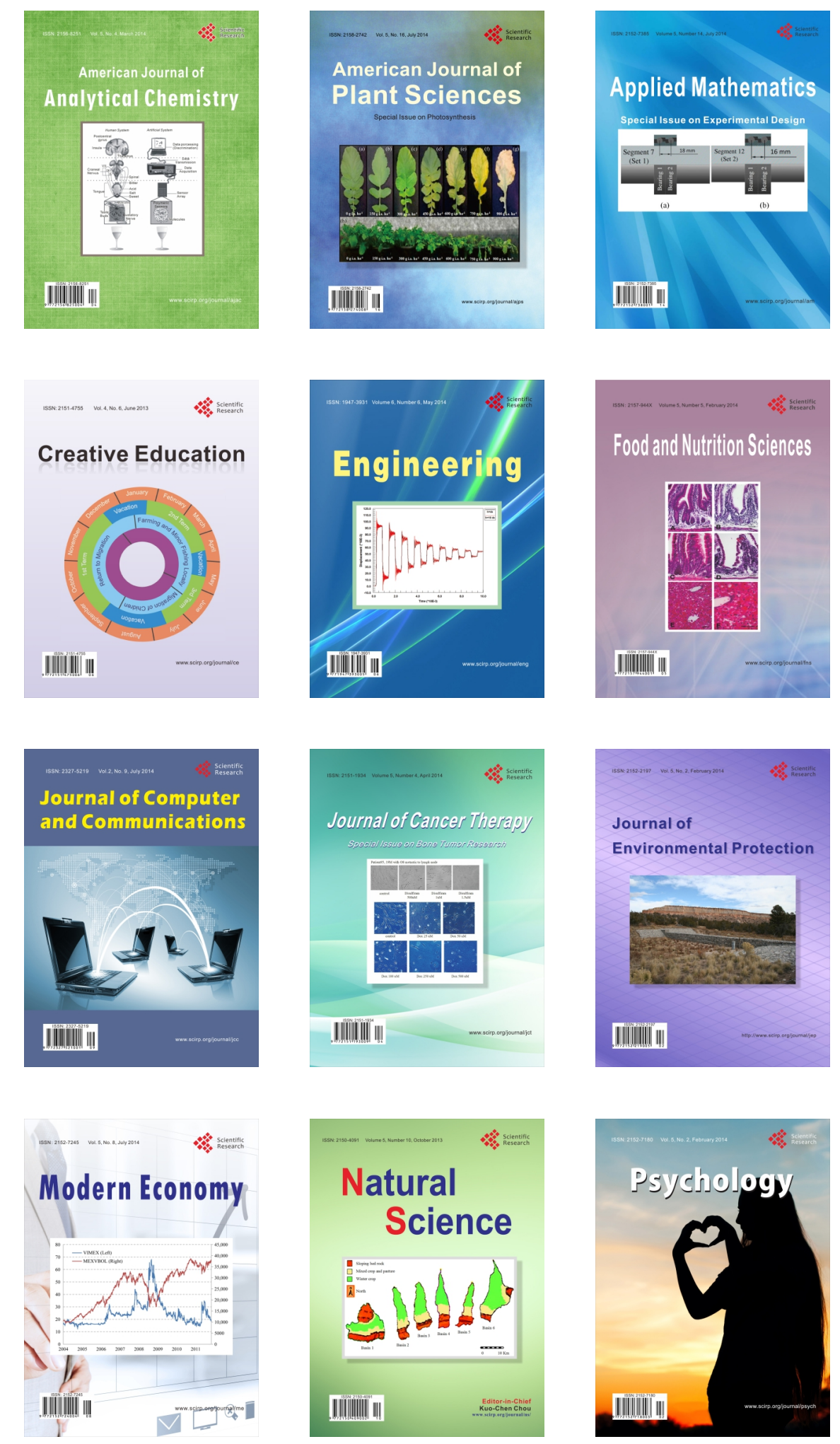